\title{
THE FORMATION OF THEORETICAL FUNDAMENTALS OF CORPORATE FINANCIAL STRATEGY
}

\author{
Kushchik A. P. \\ Zaporizhzhia National University \\ Ukraine, 69600, Zaporizhzhia, Zhukovsky str., 66 \\ 20favorit10@i.ua \\ ORCID 0000-0003-0627-2296
}

Key words:

corporate management, deterministic chaos, financial strategy, competitiveness.
The article considers topical issues of forming corporate financial strategy in the real sector of the economy. It has been shown that the development and implementation of winning strategies, "creating the future" requires the identification or the use of fundamentally new opportunities. The pioneer always gets the right to form their own rules of the game, to stabilize the novelty. This is facilitated by the application of chaos theory, which allows to create methods for diagnostics secret effects, manipulation and destructive latent management of competitiveness and strategy development.

It is noted that corporate financial strategy is an integral part and an important element of the management system of the enterprise, occupying a central place among its functional strategies, determines the main directions of improving the management of its financial activities and financial relations with counterparties. The complexity of strategy formation connects with the need of taking into account many dynamic, vague, not always formalized goals and guidelines so appear probability of forming strategy on the basis of conflicting guidelines. Thus, the strategy is a model of goals, actions, capabilities of the corporation for strategic perspective, based on the creation and implementation of which the organizing and managing of financial and other resources of a system is put down. The ideal system can be considered such a system that by changing the strategy of its behavior at some stage of development adapts to the existing projected dynamics of the environment and stabilizes its entropy at the natural level.

\section{ТЕОРЕТИЧНІ ЗАСАДИ ФОРМУВАННЯ КОРПОРАТИВНОЇ ФІНАНСОВОЇ СТРАТЕГІЇ}

\author{
Кущик А. П. \\ Запорізький начіональний університет \\ Україна, 69600, м. Запоріжжя, вул. Жуковського, 66
}

\section{Ключові слова:}

корпоративне управління, детермінований хаос, фінансова стратегія, конкурентоспроможність.
У статті розглянуто актуальні питання формування корпративної фінансової стратегії в реальному секторі економіки. Показано, що розробка i реалізація виграшних стратегій, «створення майбутнього» вимагає виявлення або використання принципово нових можливостей. Першопроходець завжди отримує право формувати свої правила гри, стабілізувати новизну. Цьому сприяє застосування теорії хаосу, яка дозволяє створювати методи діагностики прихованих впливів, маніпулювання i деструктивного латентного управління конкурентоспроможністю та стратегією розвитку.

Зазначено, що корпоративна фінансова стратегія є невід'ємною складовою частиною та важливим елементом системи менеджменту підприємства, посідаючи центральне місце серед його функціональних стратегій, визначає основні напрями підвищення ефективності управління його фінансовою діяльністю та розвитку фінансових відносин 3 контрагентами. Складність формування стратегії пов'язана 3 необхідністю врахування безлічі динамічних, нечітких, не завжди таких, що формалізуються цілей i орієнтирів, тому виникає вірогідність формування стратегії на основі суперечливих орієнтирів. Таким чином, стратегія є моделлю цілей, дій, можливостей корпорації на стратегічну перспективу, в основу створення $\mathrm{i}$ реалізації якої покладено організацію та управління фінансовими й іншими ресурсами системи. Ідеальною системою можна вважати таку систему, яка за допомогою зміни стратегії своєї поведінки на деякому етапі розвитку пристосовується до існуючої прогнозованої динаміки зовнішнього середовища і стабілізує свою ентропію на рівні природного.

\section{Statement of the problem}

The indispensable prerequisite for providing strategic opportunities for financial development of the enterprise is its financial strategy, which occupies a key position in the system of corporate management. Balance of corporate interests in the system of corporate governance in general and between its important components in particular is the main guarantee of success of a modern enterprise. All stated above allows us to state the need to substantiate the processes of formation and evaluation of financial strategy and corporate governance in their relationship, interdependence and interaction in today's dynamic environment. In any case, the company faces 
the task to form a structure of financial strategy that would allow to make optimal strategic decisions in the field of financial management. In this regard, it is relevant and promising to study the patterns of transformation of the formation of the corporation's strategy and, in particular, its financial component.

\section{Analysis of recent studies and publications}

Foreign scientists I. Ansoff, O. Vikhansky, B. Karloff, M. Porter, A. Strickland, A. Thompson, W. Sharp and others made a significant contribution to the development of strategies. Among the most important modern studies of the problems of forming financial strategies of enterprises are the works of the following Ukrainian scientists: M. Bilyk [1], V. Bugay [2], Z. Pestovska [3], K. Serdyukova [4], O. Khudyk [5], A. Cherep, O. Shapurova [6] and others. In the works of these authors various aspects of the processes of creating strategies and systems of corporate governance are considered. Meanwhile, not only the essence of the financial strategy, but also its place in the enterprise management system is not clearly defined. In particular, S.K. Bazika proposes to consider the financial strategy as an organic element of financial regulation of the enterprise:

- in methodological terms, the essence and mechanism of formation of financial strategy must be analyzed as one of the problems of financial relations, financial evaluation of the strategic goals of the enterprise;

- in the scheme of economic regulation, financial strategy should be considered as a component of the overall strategy of the enterprise together with product, investment, marketing and other types of strategic decisions [7]. Meanwhile, a single approach to substantiate the processes of financial strategy formation in the corporate governance system, taking into account the relationships, interdependence and interactions between the financial strategy and the enterprise management system is not found yet.

\section{Objectives of the article}

The objective of the work is to substantiate the theoretical and methodological approaches to the formation of an effective corporate financial strategy. In accordance with the set of goal, a number of main tasks are defined that is to explore the essence and role of corporate financial strategy; to consider features of its formation; summarize the criteria and approaches for assessing the effectiveness of the corporate financial strategy.

\section{The main material of the research}

It should be noted that financial strategy is a relatively new concept in domestic science and management practice. At the same time, it should be noted that in the foreign literature (in particular, American and European) on financial management, the concept of "financial strategy" is practically absent, scientists use such terms as "financial planning", "long-term investment decisions", in strategic management it is considered exclusively as a kind of functional strategies.

Among domestic scientists who study the essence of this concept, there is no single common approach to its interpretation. Most authors define the financial strategy of the enterprise as a system of directions of enterprise development, necessary to achieve the goals in the long run, within a certain mission.

Of course, there is no consensus on what the basic elements make up a financial strategy. The latter, as a rule, include: short-term planning and system; which controls financial flows their organizational and legal design; selection of effective financial instruments; identification and distribution of financial risks; tax planning; use of financial innovations.

Generalization and systematization of these approaches allow us to conclude that the essence of corporate financial strategy is to identify priority goals and measures to achieve them in the field of financial resources, optimize capital structure and efficient use of assets that meet the overall concept of enterprise development and ensure its implementation.

In our opinion, corporate financial strategy as a specific financial instrument has a number of features:

its main task is to outline the priority areas of activity, justify the feasibility of key projects and programs that will help maximize the company's profits in the future;

it is developed in the context of incomplete information, therefore, does not allow to predict accurately the future state, and therefore it is characterized by significant variability of strategic decisions;

it is the basis for providing financial resources to improve the efficiency of the enterprise in the long run.

Every leader in a situation of uncertainty and the risk primarily seeks to understand if not the essence, then at least the specifics of what is happening. Therefore, the idea of a stable interaction of a limited number of key factors in the causal relationship allows you to gain confidence in management decisions. In a situation of stable operation of the corporation, this leads to success and allows you to solve major problems.

This mechanistic worldview, which states that the world is taking turns, gives hope to strategists that a series of events can be foreseen if the fundamental principles are discovered and the options that can be applied are known. But the rigidity of competition, the globalization of the world economy, the complexity of political processes and their impact on economic life leads to the need to change the paradigm of strategic thinking at the corporate level. Thus, according to the theory of chaos, both destructive and constructive principles are laid down in the system itself. Even in the absence of external shocks, a successful complex system includes factors that push the system beyond stability, into turbulence and reformatting"[8]. Deviations created by the most dynamic system are self-organizing. It is important to us that similar phenomena occur in corporations, and the use of notions of "self-organized criticality" increases the power of analytical procedures in management, and ultimately in the formation of financial strategy.

The economic literature offers different approaches to the structure of the financial strategy of the enterprise. In our opinion, ways and directions of achievement of the declared purposes are defined within the limits of formation of separate components (modules) of financial strategy and its components. 


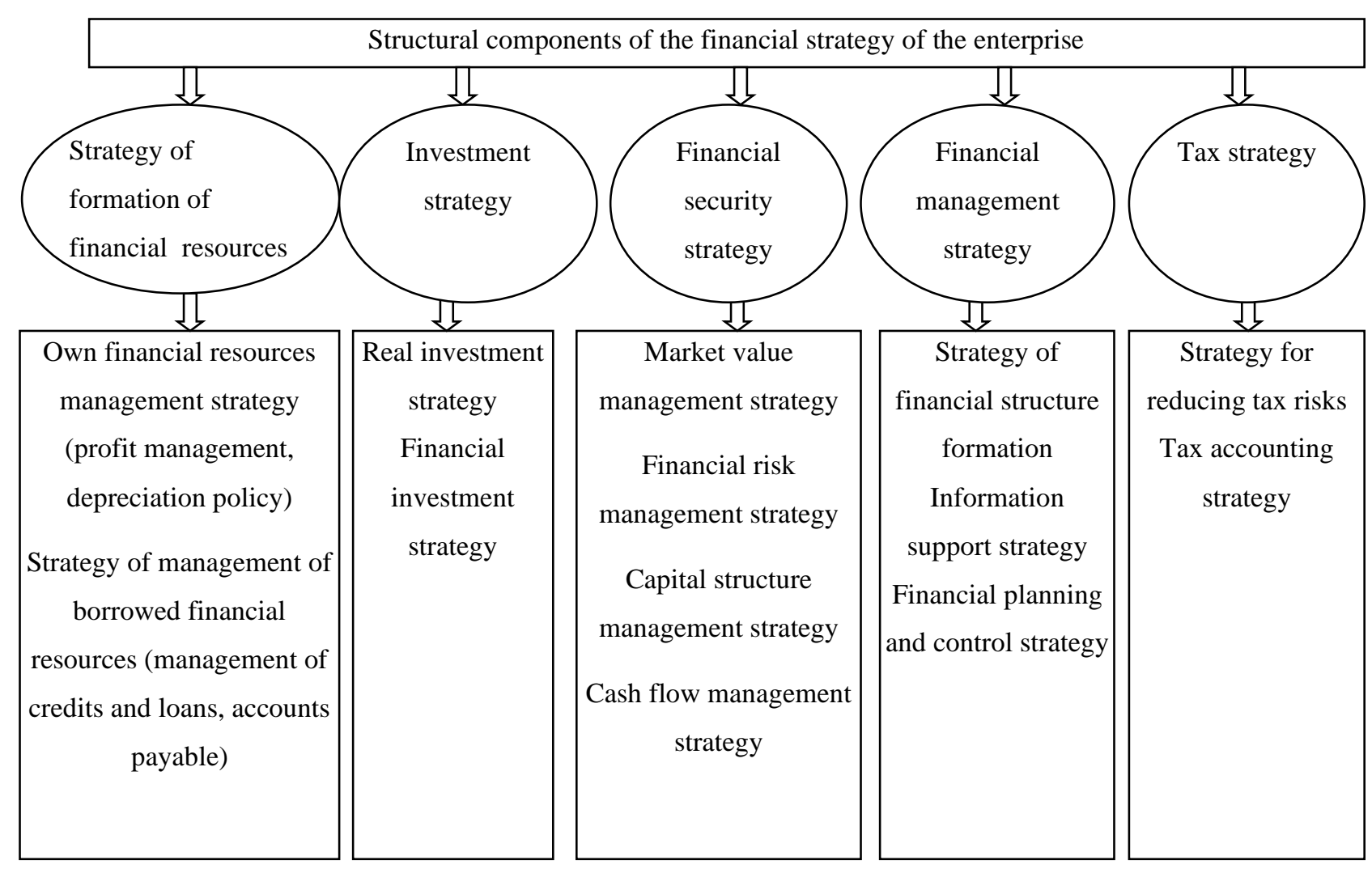

Fig. 1 - The system of components of corporate financial strategy in terms of the main directions of financial and economic development

This approach allows you to define the corporate financial strategy of the enterprise as an integrated structural composition, for example, of five interconnected and interdependent modules (financial strategies of the 2nd level).

Table 1 - Characteristics of the components of corporate financial strategy

\begin{tabular}{|c|c|c|}
\hline $\begin{array}{l}\text { Component of the } \\
\text { financial strategy of } \\
\text { the enterprise }\end{array}$ & Essence & The main strategic objectives \\
\hline 1 & 2 & 3 \\
\hline $\begin{array}{ll}\text { Strategy } & \text { of } \\
\text { formation } & \text { of } \\
\text { financial resources }\end{array}$ & $\begin{array}{l}\text { Creating the necessary amount and } \\
\text { structure of financial resources, } \\
\text { adequate to the development goals } \\
\text { that allow to achieve the strategic } \\
\text { objectives of the firm with the } \\
\text { highest efficiency. }\end{array}$ & $\begin{array}{l}\text { Achieving stable growth of own sources of financing; } \\
\text { attracting the necessary external financing with minimal } \\
\text { costs; optimizing the structure of sources of financial } \\
\text { resources and ensuring financial flexibility. }\end{array}$ \\
\hline Investment strategy & $\begin{array}{l}\text { The optimal distribution of the } \\
\text { amount of investment resources } \\
\text { owned by the company, by } \\
\text { individual areas and forms of } \\
\text { investment. }\end{array}$ & $\begin{array}{l}\text { Ensuring the necessary proportionality of the } \\
\text { distribution of investment resources by types and main } \\
\text { directions of investment activities of the enterprise; } \\
\text { ensuring the necessary proportionality of the } \\
\text { distribution of financial resources by strategic business } \\
\text { units of the enterprise; ensuring high efficiency of } \\
\text { return on investment resources of the enterprise in the } \\
\text { process of their use. }\end{array}$ \\
\hline $\begin{array}{l}\text { Financial security } \\
\text { strategy }\end{array}$ & $\begin{array}{l}\text { Ensuring a stable financial balance } \\
\text { throughout the period of operation } \\
\text { of the enterprise. }\end{array}$ & $\begin{array}{l}\text { Identification and assessment of the most significant } \\
\text { financial risks and development of a set of measures to } \\
\text { neutralize them; ensuring stable solvency and financial } \\
\text { stability, implementation of comprehensive solutions in } \\
\text { the field of crisis management (both in terms of } \\
\text { preventive measures and in terms of actions in the event } \\
\text { of signs of crisis). }\end{array}$ \\
\hline
\end{tabular}


In our opinion, the presentation of financial strategy as a composition of five basic modules is effective for the enterprise of any scale and type of activity.

The approach to the definition of corporate financial strategy as an integrated structural composition of the main modules allows you to focus on managing those areas of the financial sector that are the most important for the company in the long run.

Review and generalization of modern approaches to the sequence of development of the financial strategy of the enterprise indicates the lack of a single structural construction of this process, which allows us to conclude that it is necessary to streamline it.

First of all, it is necessary to determine the financial strategy of the corporation, in relation to its financial condition in the long run, formed on the basis of quantitative characteristics of the actual financial state in the current and subsequent periods, i.e.:

$$
\mathrm{FS}(\mathrm{t})=\mathrm{f}(\mathrm{a}(\mathrm{t}) \mathrm{a}(* * *)(\mathrm{t}) \mathrm{a}(\mathrm{t}+1),
$$

$\mathrm{FS}(\mathrm{t})$ - financial strategy of the enterprise at time $\mathrm{t}$; $\mathrm{a}(\mathrm{t})$ the actual state of the enterprise at the time; $a(* * *)(t)-$ optimal state of the enterprise at time $t ; a(t+1)-$ the forecast state of the enterprise at time $t+1$.

The most important indicator and criterion for the effectiveness of corporate financial strategy, which is formed in the process of implementing the planned strategic decisions and alternatives, is the cost of capital of the enterprise. The main strategic goal of the enterprise is to increase its value. Thus, the value of the enterprise is a criterion of efficiency and of the stage of effective of the enterprise. We emphasize that the assessment and management of the value of the enterprise are necessary not only when planning the purchase or sale of the enterprise, reorganization of the enterprise or its insurance, but first and foremost for the functioning of business [9].

The value of the enterprise can be considered as a variable multifaceted value during the existence of the enterprise. This cost can be presented through the cost of strategic activities of the enterprise:

$$
B(t)=\sum_{i=1}^{n} B i(t),
$$

where $\mathrm{B}(\mathrm{t})$ - the cost of the enterprise in time, $\mathrm{UAH} ; \mathrm{Bi}(\mathrm{t})$ - the cost of the i-th direction in time, UAH; $n$ - the number of strategic activities.

The indicator of current value management of the enterprise can be described by formula (3):

$$
Y_{j_{\mathrm{nom}}}=-K * \Delta B_{j}(t),
$$

where $\mathrm{Y}$ - current value management of the enterprise; $\mathrm{K}$ - matrix of control parameters; $\Delta \mathrm{Bj}(\mathrm{t})$ - deviation of indicators on the $\mathrm{j}$-th step of managin

The current financial strategy cannot be assessed by one general indicator. Such an assessment can be made on the basis of the obtained results, which are reflected in the efficiency and performance of the enterprise - internal, external and overall economic efficiency. The evaluation of the selected performance criteria should be carried out in complex, as the proposed indicators are interrelated and interdependent. Based on the results of the evaluation, the financial strategy is accepted for implementation or completed according to the specified criteria.

\section{Conclusions}

The formation of corporate financial strategy of the enterprise should be carried out taking into account: the influence of external and internal factors on the activities of the enterprise; availability of production, financial, marketing and human resources. Depending on this, companies can form such financial strategies that will achieve a positive result, in particular, to stabilize their financial stability, profitability, competitiveness, to maintain certain market positions. After all, the right choice of financial strategy is a necessary condition for improving the management of enterprises and increase the efficiency of their activities.

It is offered the improvement of the organizational mechanism of financial strategy formation in the system of corporate management, which is based on the dominants and the model of formation of financial strategy of the enterprise. This mechanism takes into account the relationships, interdependence and interaction between the corporate governance system and its component - the financial strategy of the enterprise, which allows more reasonable development of practical recommendations for financial development of enterprises, taking into account their strategic capabilities. From the standpoint of a systems approach, these performance criteria must meet certain requirements: first, meet the objectives of the enterprise; secondly, to be connected with the external and internal environment in which the enterprise operates, because only by external criteria it is not possible to determine the effectiveness of its work; third, to have completeness of making necessary decisions; fourth, to be clear (to make economic sense); fifth, be available for receipt.

\section{References}

1. Bilyk M. D. (2015). Rozrobka financovoi strategy na pidpriemstvi. [Development of financial strategy at the enterprise]. Formuvannya rinkovih vidnosin v Ukraini. Formation of market relations in Ukraine, 6, 158-164. [in Ukrainian].

2. Bugay V.Z, \& Riznik V.S. [2017]. Formuvanya finansovoi strategiyi pidpryemstva v suchasnih umovah [Formation of the financial strategy of the enterprise in modern conditions]. Visnik Zaporizkogo naztionalnogo universitetu. Ekonomichni nauki. Bulletin of Zaporizhia National University. Economic sciences, 3. 20-26. [in Ukraine].

3. Pestovska Z.S. \& Gritsenko E.G. (2017). Formuvanya finansovoi strategii pidpriyemstva na osnovy modifikatsii sistemi sbalansovanih pokaznikiv. [Formation of the financial strategy of the enterprise on the basis of modification of the system of balanced indicators]. Akademichniy oglyad. Academic review, 2, 21-31. [in Ukraine]. 
4. Serdyukov K.G. \& Malyshkina K.Y. (2018). Sutnisna kharakteriatika korporativnoi finansovoi strategii gospodaryuyuchogo subekt. [The essential characteristics of the corporate financial strategy of the business entity]. Bulletin of KhNAU. Series: Economic Sciences, 1, 258-266. [in Ukraine].

5. Khudik O.B. (2017). Obgruntuvanya finansovoi strategii na osnovy sistemnogo analysu. [Substantiation of financial strategy based on system analysis]. Bulletin of Khmelnytsky National University. Economic sciences, 2 (1), 114-121. [in Ukraine].

6. Shapurova O.O. (2018). Pidkhodi do formuvanya finansovoi strategii promislovogo pidpriyemstva: teoretichny ta praktichny aspekty. [Approaches to the formation of the financial strategy of an industrial enterprise: theoretical and practical aspects]. Bulletin of Odessa National University. Series: Economics. T. 23, 6, $113-118$. [in Ukraine].

7. Bazika S.K. (2018). Byudzhetne planuvanya yak instrument finansovogo strategichnogo upravlinya. [Budget planning as a tool of financial strategic management]. Investments: practice and experience, 18, 114-118. [in Ukraine].

8. Mann S. (1992). Teoriya khaosa I strategicheskaya misl. [Chaos theory and strategic thought]. Parameters. Retrieved from http: // conservatism. org / konservatizm / theory / 080310032055.xhtml. [in Ukraine].

9. Babyak N.D. \& Bilotska I.A. (2018). Biznes seredovishche - korporativni finansovi strategii: problemy sinkhronizatsii v Ukraine. [Business environment - corporate financial strategies: problems of synchronization in Ukraine]. Intelligence XXI, 6, 137-141. [in Ukraine]. 